\title{
Effect of Physical, Chemical and Biological Mechanisms on the Solid-Liquid Separation of Microalgae
}

\author{
Raquel Rezende dos Santos*, Juliana Leite Pinto, Gabriel Lima de Figueiredo Teixeira, José Luiz de Medeiros \\ and Ofélia de Queiroz Fernandes Araújo \\ Escola de Química, Federal University of Rio de Janeiro, Brazil
}

Submission: September 01, 2018; Published: October 04, 2018

*Corresponding author: Raquel Rezende dos Santos, Escola de Química, Federal University of Rio de Janeiro, Av Horácio Macedo, Centro de Tecnologia, Bl E, Sala 201, Rio de Janeiro, RJ, Brazil, Tel: +55 21 3938-7357; Email: raquel.c.rezende@gmail.com

\begin{abstract}
The use of microalgae biomass as bioenergy has been an effective strategy to reduce $\mathrm{CO} 2$ emissions. However, downstream steps such as harvesting, and pretreatment are crucial for efficient biomass processing. These steps still meet the industrial bottleneck related to cost and feasibility Microalgae harvesting is still a great challenge and can occur by different factors. In this way, the work aims to explore efficient mechanisms of solidliquid separation of microalgae for large-scale reproduction. For this, the microalga Isochrysis galbana and the cyanobacterium Spirulina maxima were submitted to solid-liquid separation by physical (i.e., centrifugation), chemical (i.e., chemical flocculant) and biological (i.e., temperature, irradiance, growth phase) actions. The results suggested that the chemical flocculation of both strains showed a better cost-benefit ratio.
\end{abstract}

Keywords: Flocculation; Flotation; Harvesting; Microalgae; Sedimentation

\section{Introduction}

Sustainable energy production is one of the most important resources for humanity. Sunlight is a vital energy source for the Earth and photosynthesis is the main biological process that channels solar energy into the biosphere [1]. Microalgae are a very heterogeneous group of organisms that performs high photosynthetic efficiency and $\mathrm{CO}_{2}$ absorption, contributing to the reduction of greenhouse gases. In recent years, the major focus of applied phycological research have attracted a great deal of interest as potential tools for producing different compounds, such as high-value chemicals, pharmaceuticals, food supplements and biofuels [2,3]. Thus, different strains of microalgae are used in different purposes, in order to generate high biomass and bioproducts productivity with low harvest cost $[4,5]$.

Among the advantages of using microalgae, they are cultivable throughout the year, can grow in reuse water and in non-arable land without altering soil use, minimizing the associated environmental impacts, without compromising food production $[6,7]$. Many strategies being employed to generate microalgae biomass. Therefore, important considerations include strain selection, cultivation methods, separation and pretreatment processes. Strain selection plays an important role because microalgae biodiversity differs in their productivity. Separation and pretreatment affect the total amount of harvested microalgae and the downstream process [8].
The microalgae transformation in high-value products consists of process steps that induce high energy needs. One of the main reasons is the lack of a highly integrated process for harvesting [9]. While it is essential to reduce the cost of the production process, little progress has been made in research into downstream processing. The microalgae harvest is still a great challenge, which resides in the microalgae separation from its growth medium. Due to the size of the microalgae, harvesting by sedimentation is not feasible, besides the negatively charged surfaces of the microalgae prevent them from settling easily by gravity $[9,10]$. Additionally, certain cyanobacteria (i.e., prokaryotic microalgae) have gas vesicles and are known to use these vesicles to move to a more favorable upright position, making them difficult to harvest using sedimentation and centrifugation [11].

The microalgae harvest basically comprises two steps: thickening and dehydration, which can occur by mechanical, electrical, chemical and biological. Mechanical methods are most commonly used to harvest microalgae biomass. However, often preceded by a chemical or biological, to optimize the thickening phase in order to reduce operation and maintenance costs [12]. An ideal harvesting process should be effective for most strains of microalgae, although it presents moderate energy costs and maintenance. The selection of a suitable harvest depends on the final product, namely its value and properties. It is also desirable 
that the harvest method be associated with the recycling of the culture medium [13].

Considering the obstacles still found in harvest stage of the microalgae industrial processing, this study aims to evaluate the effect of physical (i.e., centrifugation), chemical (i.e., chemical flocculant) and biological (i.e., temperature, irradiance, growth phase) mechanisms on the solid-liquid separation of microalgae and the possibility of large-scale reproduction, discussing the advantages and disadvantages of each process, its applicability, cost-benefit and efficiency.

\section{Materials and Methods}

\section{Microalgae and culture medium}

Microalga Isochrysis galbana provided from Federal Fluminense University (Rio de Janeiro, Brazil) and cyanobacterium Spirulina maxima obtained from Federal University of São Carlos (São Paulo, Brazil) were maintained in $250 \mathrm{~mL}$ Erlenmeyer flasks containing $125 \mathrm{~mL}$ of $\mathrm{F} / 2$ medium and $\mathrm{AO}$ medium $[14,15]$, respectively. Modified culture mediums were sterilized by autoclaving at $121^{\circ} \mathrm{C}$ and $1 \mathrm{~atm}$ for 20 minutes, except vitamins that were filtrated with cellulose membrane $(0.22 \mu \mathrm{m}$ porosity, SARTORIUS $®$ ).

Flasks were kept in a rotary shaker set at 110rpm (ETHIK TECHNOLOGY, model 109-01, Brazil, 25mm orbital motion), 20 $\mu$ mol photons m-2 s-1 photon flux density (PFD) provided by fluorescent bulbs in 12:12 $\mathrm{h}$ photoperiod and temperature of $25 \pm 2^{\circ} \mathrm{C}$. PFD measurements were carried out using an integrated quantum meter LI-250A (Li-Cor Inc., USA) equipped with a cosine-corrected planar quantum sensor LI- 190SA (Li-Cor Inc., USA). Sensor was located at the external surface of culture flasks.

The F/2 medium was composed of artificial seawater (33 g $\mathrm{L}^{-1}$, Ocean Fish, Prodac $\left.\AA\right)$ enriched with $\mathrm{NaNO}_{3}\left(74.8 \mathrm{mg} \mathrm{L}^{-1}\right)$, $\mathrm{Na}_{2} \mathrm{HPO}_{4} .2 \mathrm{H}_{2} \mathrm{O}\left(5.6 \mathrm{mg} \mathrm{L}^{-1}\right)$, citric acid $\left(4.1 \mathrm{mg} \mathrm{L}^{-1}\right)$, ferric citrate (3.3 mg L$\left.{ }^{-1}\right), \mathrm{CoCl}_{2} \cdot 6 \mathrm{H}_{2} \mathrm{O}\left(0.011 \mathrm{mg} \mathrm{L}^{-1}\right), \mathrm{CuSO}_{4} \cdot 5 \mathrm{H}_{2} \mathrm{O}\left(0.01 \mathrm{mg} \mathrm{L}^{-1}\right)$, $\mathrm{MnCl}_{2} \cdot 4 \mathrm{H}_{2} \mathrm{O}\left(0.18 \mathrm{mg} \mathrm{L}^{-1}\right), \mathrm{NaMoO}_{4} \cdot \mathrm{H}_{2} \mathrm{O}\left(0.006 \mathrm{mg} \mathrm{L}^{-1}\right), \mathrm{ZnSO}_{4} \cdot 7 \mathrm{H}_{2} \mathrm{O}$ $\left(0.022 \mathrm{mg} \mathrm{L}^{-1}\right)$, biotin $\left(0.005 \mathrm{mg} \mathrm{L}^{-1}\right)$, cyanocobalamin $(0.005 \mathrm{mg}$ $\left.\mathrm{L}^{-1}\right)$ and thiamine $\mathrm{HCl}\left(0.101 \mathrm{mg} \mathrm{L}^{-1}\right)$.

The AO medium was composed of $\mathrm{NaHCO}_{3}\left(13.6 \mathrm{~g} \mathrm{~L}^{-1}\right), \mathrm{Na}_{2} \mathrm{CO}_{3}$ (4.0 $\left.\mathrm{g} \mathrm{L}^{-1}\right), \mathrm{K}_{2} \mathrm{HPO}_{4}\left(0.5 \mathrm{~g} \mathrm{~L}^{-1}\right), \mathrm{NaNO}_{3}\left(2.5 \mathrm{~g} \mathrm{~L}^{-1}\right), \mathrm{K}_{2} \mathrm{SO}_{4}\left(1.0 \mathrm{~g} \mathrm{~L}^{-1}\right)$, $\mathrm{NaCl}\left(1.0 \mathrm{~g} \mathrm{~L}^{-1}\right), \mathrm{MgSO}_{4} .7 \mathrm{H}_{2} \mathrm{O}\left(0.2 \mathrm{~g} \mathrm{~L}^{-1}\right), \mathrm{CaCl}_{2} \cdot 2 \mathrm{H}_{2} \mathrm{O}\left(0.04 \mathrm{~g} \mathrm{~L}^{-1}\right)$, $\mathrm{Na}_{2}$ EDTA. $2 \mathrm{H}_{2} \mathrm{O}$

(0.08 $\left.\mathrm{g} \mathrm{L}^{-1}\right), \mathrm{FeSO}_{4} .7 \mathrm{H}_{2} \mathrm{O}\left(0.01 \mathrm{~g} \mathrm{~L}^{-1}\right), \mathrm{H}_{3} \mathrm{BO}_{3}\left(2.9 \mathrm{mg} \mathrm{L}^{-1}\right)$, $\mathrm{MnCl}_{2} \cdot 4 \mathrm{H}_{2} \mathrm{O}\left(1.8 \mathrm{mg} \mathrm{L}^{-1}\right), \mathrm{ZnSO}_{4} \cdot 7 \mathrm{H}_{2} \mathrm{O}\left(0.22 \mathrm{mg} \mathrm{L}^{-1}\right), \mathrm{Na}_{2} \mathrm{MoO}_{4} \cdot 2 \mathrm{H}_{2} \mathrm{O}$ $\left(0.39 \mathrm{mg} \mathrm{L}^{-1}\right), \mathrm{CuSO}_{4} \cdot 5 \mathrm{H}_{2} \mathrm{O}\left(0.079 \mathrm{mg} \mathrm{L}^{-1}\right)$ and $\mathrm{Co}\left(\mathrm{NO}_{3}\right)_{2} \cdot 6 \mathrm{H}_{2} \mathrm{O}$ $\left(0.049 \mathrm{mg} \mathrm{L}^{-1}\right)$.

\section{Obtainment and monitoring of biomass}

To obtain the inoculum, cells were grown in $500 \mathrm{~mL}$ Erlenmeyer flasks containing $250 \mathrm{~mL}$ of culture medium. Culture flasks were maintained at $70 \mu \mathrm{mol}$ photons $\mathrm{m}^{-2} \mathrm{~s}^{-1}$ in $12: 12 \mathrm{~h}$ photoperiod and $25 \pm 3{ }^{\circ} \mathrm{C}$. Cultures were gassed with filtered atmospheric air pumped by aquarium compressors with 800 $\mathrm{mL}$ min-1 airflow. Obtained inoculums during exponential growth phase were transferred to $4 \mathrm{~L}$ flasks containing $2 \mathrm{~L}$ of culture medium. Cultivations were maintained until cells achieve stationary growth phase.

Growth cell were monitored by measuring the optical density (OD) (SHIMADZU, model UV-1800 ENG 120V). Growth curves were built with dry mass (DM) values in logarithmic scale. OD was converted to DM ( $\mathrm{g} \mathrm{L}^{-1}$ ) of I. galbana and S. maxima as shown in Eq. (1) and (2), respectively.

$$
\begin{aligned}
& D M=\frac{\left(\mathrm{OD}_{750 \mathrm{~nm}}-0.0085\right)}{2.5547}\left(\mathrm{R}^{2}=0.98\right) \\
& D M=\frac{\left(\mathrm{OD}_{730 \mathrm{~nm}}\right)}{1.8158}\left(\mathrm{R}^{2}=0.99\right)
\end{aligned}
$$

DM was obtained by vacuum filtering through fiber glass membranes $(0.45 \mu \mathrm{m}$ porosity, SARTORIUS $囚)$ previously weighed [16]. Membranes were dried in oven (ICAMO, model 3) at $100{ }^{\circ} \mathrm{C}$ to a constant weight, cooled in desiccator and weighed again. DM was calculated by subtraction between the final weight and the initial weight of the membrane. Cell concentration was measured in terms of DM $\left(\mathrm{g} \mathrm{L}^{-1}\right)$.

\section{Solid-liquid separation of microalgae}

Obtained biomass was harvested by different mechanisms with physical, chemical and biological action. Measurement of $\mathrm{pH}$ was estimated using a $\mathrm{pH}$ meter (ANALYSER COMÉRCIO E INDÚSTRIA LTDA, model 300) and the cell disruption was observed by optical microscopy (Bioval, model L1000B).

\section{Separation by physical mechanism}

The centrifugation process (CIENTEC, model CT 6000R) was conducted at $20^{\circ} \mathrm{C}$ with round bottom flasks containing $60 \mathrm{~mL}$ of cultivation in different combinations of acceleration $(320,537$, 840, 1209 and $1646 \mathrm{~g}$ ) and time (1, 2, 3, 5, 10 and 15 minutes), according to each strain. An aliquot was withdrawn from the middle of the supernatant column of the samples to analyses the harvesting efficiency and cell disruption.

\section{Separation by chemical mechanism}

Chemical separation occurred in beakers containing $50 \mathrm{~mL}$ of cultivation and $1 \mathrm{~mL}$ of $\mathrm{NaOH}$ (1, 2, 3, 4 and 5M). Cell suspensions were homogenized thrice and incubated at $25^{\circ} \mathrm{C}$ during 10,30 , $60,90,120$ and 150 minutes according to the strain. Change of $\mathrm{pH}$ values were measured after incubation time. To observe the harvesting efficiency and cell disruption, an aliquot was withdrawn from the upper or the lower portion of the suspension column, depending on the cell behavior (i.e., sedimentation for $I$. galbana and flotation for S. maxima).

\section{Influence of the temperature and irradiance on mi- croalgae harvest}

To evaluate the influence of temperature on metabolism and I. galbana harvest, beakers containing $50 \mathrm{~mL}$ of cultivation were incubated in thermostatic bath (QUIMIS, model Q214M2) at 5, 15, 25,35 and $45^{\circ} \mathrm{C}$ during 60,120 and 180 minutes. The influence of irradiance on vertical cell migration at $25{ }^{\circ} \mathrm{C}$ was observed incubating beakers containing $50 \mathrm{~mL}$ of cultivation at 30,100 , 
200, 300 and $500 \mu \mathrm{mol}$ photons $\mathrm{m}-2 \mathrm{~s}-1$ (provided and measured as quoted in section 2.1) during 60, 120 and 180 minutes. The harvesting efficiency was measured. An aliquot was withdrawn from the upper portion of the suspension column to measure the harvesting efficiency and cell disruption.

\section{Influence of the growth phase on microalgae harvest}

To analyze the impact of the growth phase on S. maxima harvest, separation by physical and chemical mechanisms (as quoted in sections 2.3.1 and 2.3.2) was also realized during exponential growth phase because of its variation in the cell content.

\section{Harvesting efficiency}

Harvesting efficiency was represented as OD reduction, which was calculated by the difference between the OD obtained before (initial OD) and the OD quantified after the separation mechanism. Percent OD reduction was calculated as a ratio between the OD reduction and the initial OD.

\section{Statistical analysis}

The set of continuous probability distributions pertinent to this work encompasses Normal Distribution with mean, variance and t-Student Distribution $[17,18]$. To accomplish the analysis, three statistics were invoked: Sample Mean (SM); Sample Variance (SV) and Sample Standard Deviation (SStD).

Solid-liquid separations were observed in duplicate being extensively used to establish $95 \%$ probability $(\alpha=0.05)$ confidence limits for all realized assays with the appropriate t-Student abscissa. Statistical analysis is summarized in the Supplementary Material.

\section{Results and Discussion}

Several factors can influence microalgae separation (e.g., form and cell size, ionic strength and $\mathrm{pH}$ ) existing numerous harvest mechanisms [19]. The strains were selected due to their biotechnology importance and different characteristics. While I. galbana is a golden-brown Haptophyta, unicellular with elliptical form (length $\sim 5-6 \mu \mathrm{m}$, width $\sim 2-4 \mu \mathrm{m}$ ) and flagellate [20]; S. maxima is a green cyanobacterium, filamentous with tightly coiled trichomes (length $\sim 50-500 \mu \mathrm{m}$, width $\sim 3-4 \mu \mathrm{m}$ ) and its movement in the water column is oriented by gas vesicles [21]. These differences between the strains were relevant for the experimental analysis.

\section{Separation by physical mechanism}

Figure 1a presents harvesting efficiency in centrifugation process of I. galbana. Centrifugal forces as from $537 \mathrm{~g}$ demonstrate OD reduction above $80 \%$, whereas intensities and exposition times as from $1209 \mathrm{~g}$ shows low influence on cell sedimentation (around 95.3-99.9\%). S. maxima centrifugation at 1, 2, and 3 minutes was not satisfactory (data not shown) being necessary evaluate the separation at 5, 10 and 15 minutes (Figure 1b). Maximum OD reduction was $85.5 \%$ at $1646 \mathrm{~g}$ for 10 minutes. For both strain, gravitational and shear forces did not generate cell disruption.।

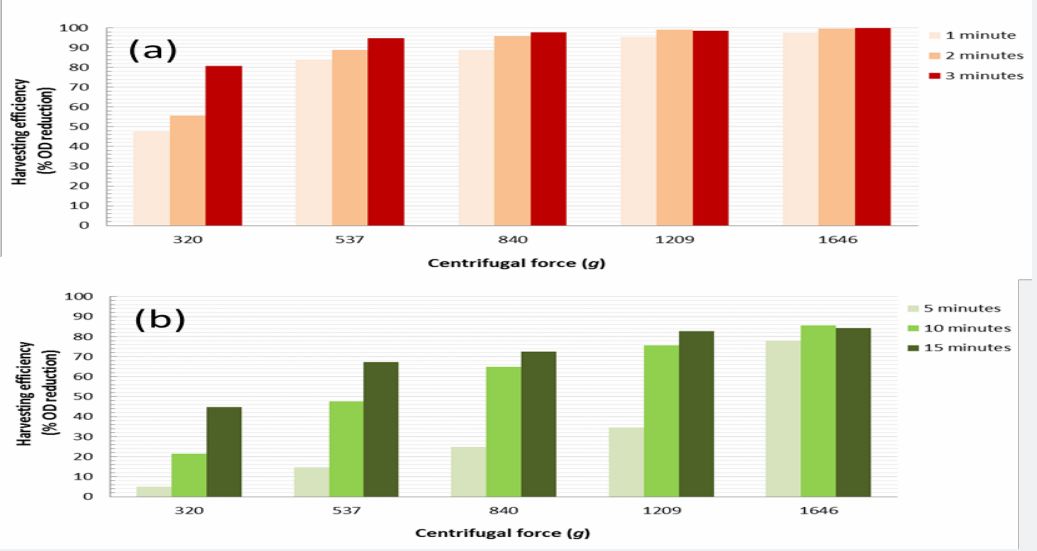

Figure 1: Harvesting efficiency in centrifugation process of $I$. galbana (a) and S. maxima (b) during several intensities and exposition times.

Centrifugation process consists on the generation of a centrifugal force that acts radially separating particles based on the density difference between the particle and the surrounding medium [22]. Although centrifugation is a recurrent method for microalgae harvest (can recover $80-90 \%$ of biomass within $2-5$ minutes), the energy demand is high for industrial applications [21]. Kim et al. [23] analyzed various harvesting methods for the high-density microalga Aurantiochytrium sp. Among the tested means, centrifugation (1000-9000 g for 30 minutes) demonstrated lower water content in harvested biomass with harvesting efficiency between 84.6-87.2\%. In terms of energy consumption, centrifugation was the costliest (1.94 W hg-1).

\section{Separation by chemical mechanism}

Figure 2 exhibits harvesting efficiency in solid-liquid separation mediated by $\mathrm{NaOH}$. As demonstrated in centrifugation process, microalga recovery varies between $48-100 \%$ and cyanobacterium recovery at 10,30 , and 60 minutes was not satisfactory being necessary evaluate the separation at 90,120 and 150 minutes. It is satisfactory apply $4 \mathrm{M} \mathrm{NaOH}$ during 30 minutes for $I$. galbana recovery (recovery was $99.6 \%$ ). Regarding to S. maxima, maximum recovery was $80.7 \%$ at $5 \mathrm{M} \mathrm{NaOH}$ during 150 minutes. For both strain, chemical interactions did not generate cell damage. 

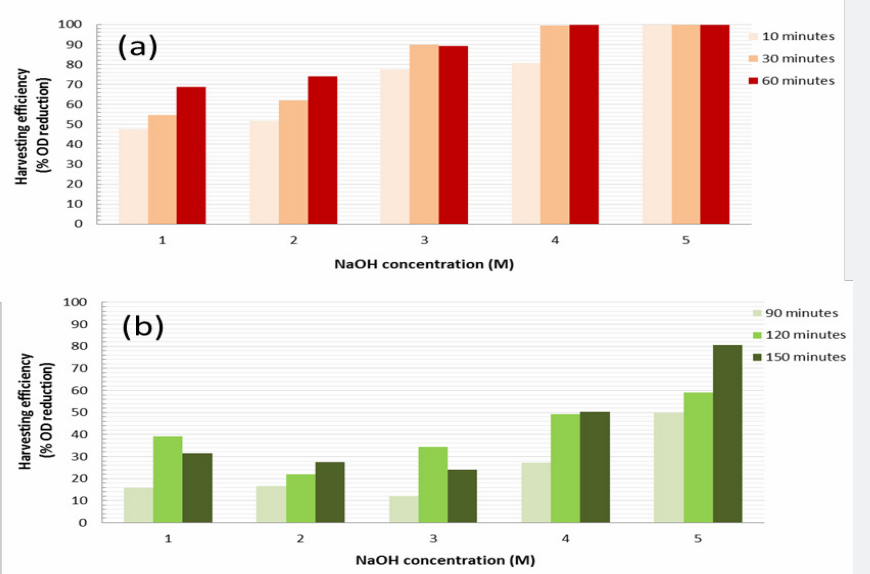

Figure 2: Harvesting efficiency of $I$. galbana (a) and S. maxima (b) during chemical flocculation mediated by $\mathrm{NaOH}$ at different concentrations and incubation times.

Flocculants addition can help in the colloids and suspensions removal accelerating the clarification process. Microalgae cells carry a negative surface charge originates predominantly of the presence of carboxylic and amine groups on the cell surface. To maintain electrical neutrality, charged cells will attract cations of the solution (e.g., $\mathrm{NaOH}, \mathrm{NH}_{4} \mathrm{OH}, \mathrm{AlC}_{13}$ ) [24]. System of negative surface charge and associated cations in the surrounding solution is known as electrical double layer, being the potential difference between the bulk fluid and the cation layer defined as Zeta potential. When the Zeta potential is high, repulsion in the electrical double layer is strong (stable system). When the Zeta potential is close to zero, electrical double layer will be attracted by Van der Waals forces formatting larger aggregates and flocks (flocculation) [10].

Many studies about flocculation of microalgae have focused on a single species cultured under one particular condition.

However, flocculation depends on the properties of cell surfaces that differ between species and vary within a species depending on culture conditions. In microalgae suspensions, compacts flocks change the density facilitating the gravity sedimentation. For some strains of cyanobacteria, the mechanism is different due to the gas vesicles. These vesicles, formed solely of protein, are inert, hollow and gas-filled structures [25]. Water content within the cell can be adjust using gas vacuoles, thus cell density can be lower than that of surrounding water. In this situation, dense flocks induce the flotation [26].

The $\mathrm{pH}$ also is an important variable considering that determines the net surface charge (positive, negative or even neutral) on the cell surface influencing flocculation performance. Figure 3 shows $\mathrm{pH}$ values after separation by chemical mechanism. Initial $\mathrm{pH}$ of the microalga suspension was 7.38 and $\mathrm{NaOH}$ addition increased this value from 9.7-10.9. Cyanobacteria are most prominent in neutral to alkaline $\mathrm{pH}$ being the initial suspension $\mathrm{pH}$ from 9.2. After flotation, $\mathrm{pH}$ values of the cyanobacterium suspension were between 9.3-10.

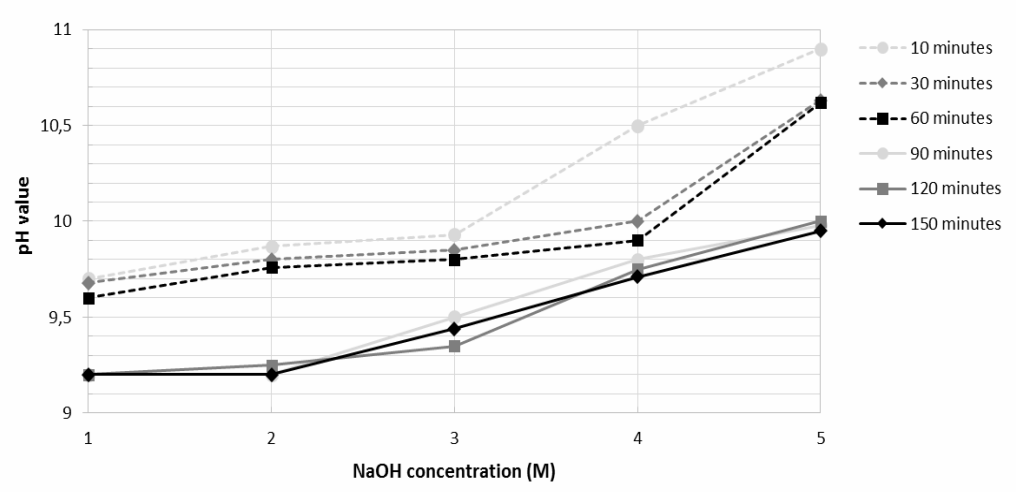

Figure 3: Change of $\mathrm{pH}$ values of the cell suspensions measured after incubation time with $\mathrm{NaOH}$. Dashed lines indicate cell suspension of l. galbana (initial pH of the microalga suspension was 7.38). Full lines indicate cell suspension of $\mathrm{S}$. maxima (initial pH of the cyanobacterium suspension was 9.2).

The pH increase (i.e., 9.7-10.9 at assays using 4-5 $\mathrm{M} \mathrm{NaOH} \mathrm{-}$ Figure 3) induced flocculation (Figure 2), inasmuch cell presented lesser surface electrostatic charge. Sales \& Abreu obtained similar results in relation the influence of the $\mathrm{pH}$ when they investigated Nannochloropsis oculata flocculation mediated by chemical and biological flocculant [27]. Flocculation more efficient significantly 
(70\%) was obtained for the culture with pH 9.6 (added from $5 \mathrm{mM}$ $\mathrm{NaOH}$ and $0.5 \mathrm{ppm}$ from bioflocculant) representing an economy from $20 \%$ with flocculant in the costs of crop harvesting [28,29].

According to Kim et al. [11] cyanobacteria harvest employing centrifugation is hampered by their physiology being more effective flotation activity. Effect of several chemical and biological flocculants have been studied as $\mathrm{Ca}_{2} \mathrm{Cl}$ [28], $\mathrm{Al}_{2}\left(\mathrm{SO}_{4}\right)_{3}$ [29], $\mathrm{Fe}_{3} \mathrm{O}_{4}$ [30], chitosan [31], Moringa oleifera [32] and $\gamma$-glutamic acid [33]. Although efficient, the use of flocculants can make not viable reuse of culture medium and it contaminate the biomass. In specific case of S. maxima, supernatant recycling containing $\mathrm{NaOH}$ is not a problem due to alkaline cell nature.
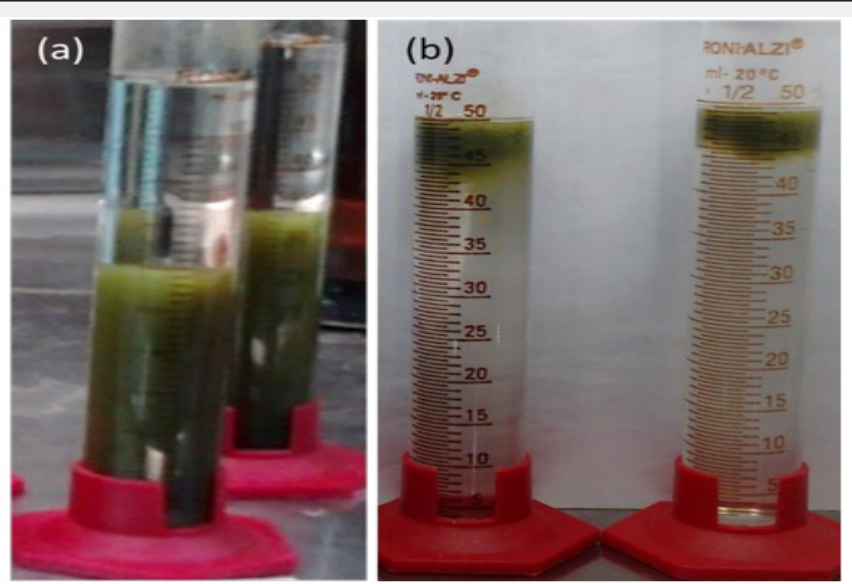

Figure 4: Algal behavior during harvesting mediated by $\mathrm{NaOH}$ : sedimentation of the microalga $\mathrm{l}$. galbana on stationary growth phase $(0.2 \mathrm{~g}$ $\mathrm{L}-1)$ mediated by $5 \mathrm{M} \mathrm{NaOH}$ during 60 minutes (a); flotation of the cyanobacterium $\mathrm{S}$. maxima on exponential growth phase $(0.4 \mathrm{~g} \mathrm{~L}-1)$ mediated by $5 \mathrm{M} \mathrm{NaOH}$ during 150 minutes (b).

Flotation results reflect the need to employ a fotobiorreactor/ container that permits medium withdraw in the lower portion without to endanger the formed flocks in the upper portion. Figure 4 illustrates sedimentation and flotation behavior during algal harvest by $\mathrm{NaOH}$. Considering same cell volume (i.e., $50 \mathrm{~mL}$ of cultivation), cell concentration of I. galbana and S. maxima were, respectively, $0.2 \mathrm{~g} \mathrm{~L}-1$ and $0.4 \mathrm{~g}$ L-1. Still with different cell density, which is prevenient of the content and cell size, it is notorious that harvested S. maxima demonstrated lower water content than harvested I. galbana demonstrating efficacy of flotation by gas vacuoles.

\section{Influence of the temperature and irradiance on mi- croalgae harvest}

Knowing that I. galbana is mobile and their flagellar movement can be oriented by environmental factors, it was observed influence of the temperature and irradiance on vertical cell migration. According to the Figure 5a, brown microalga not demonstrated consistent response pattern for temperature variations. Although the change of temperature can influence accelerating or reducing cell metabolism, this effect is not statistically relevant in I. galbana harvest. In addition, prolonged exposure at $35-45^{\circ} \mathrm{C}$ generated cell lysis. Likewise, harvesting efficiency was statistically constant (around 52.2-62.1\%) during irradiance variations (Figure 5b).
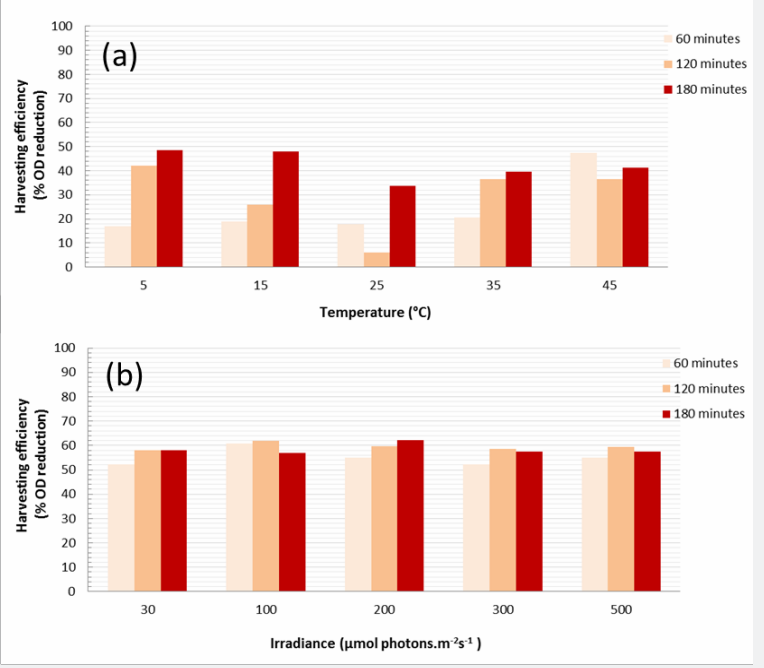

Figure 5: Harvesting efficiency of I. galbana under influence of the temperature (a) and irradiance (b). 
Some studies have reported the influence of temperature in flocculants action. Xueqian et al. [34] evaluated the effect of heat treatment in the Chlorella vulgaris flotation by bioflocculant. Authors demonstrated stable flotation at a range of temperatures ranging between $10-40^{\circ} \mathrm{C}$. Yi et al. [35] analyzed harvesting Chlorella protothecoides using the temperature-activated phase transition of thermoresponsive polymers. When the heating temperature increased, the polymer aggregation increased, and hence, the microalgal separation was facilitated.
Some gas-vacuolate photosynthetic system have shown to lose buoyancy due to turgor pressure in cyanobacteria exposed to high photon irradiances. In other systems, gas vacuoles can attenuate light penetration in cell suspensions [25]. In cyanobacteria, the mechanism of buoyancy regulation may involve modulation of gas vesicle gene expression [36], collapse of gas vesicles (e.g., turgor pressure, sonication)

[37] and cell density (e.g., carbohydrate content or other dense substances).

\section{Influence of the growth phase on microalgae harvest}

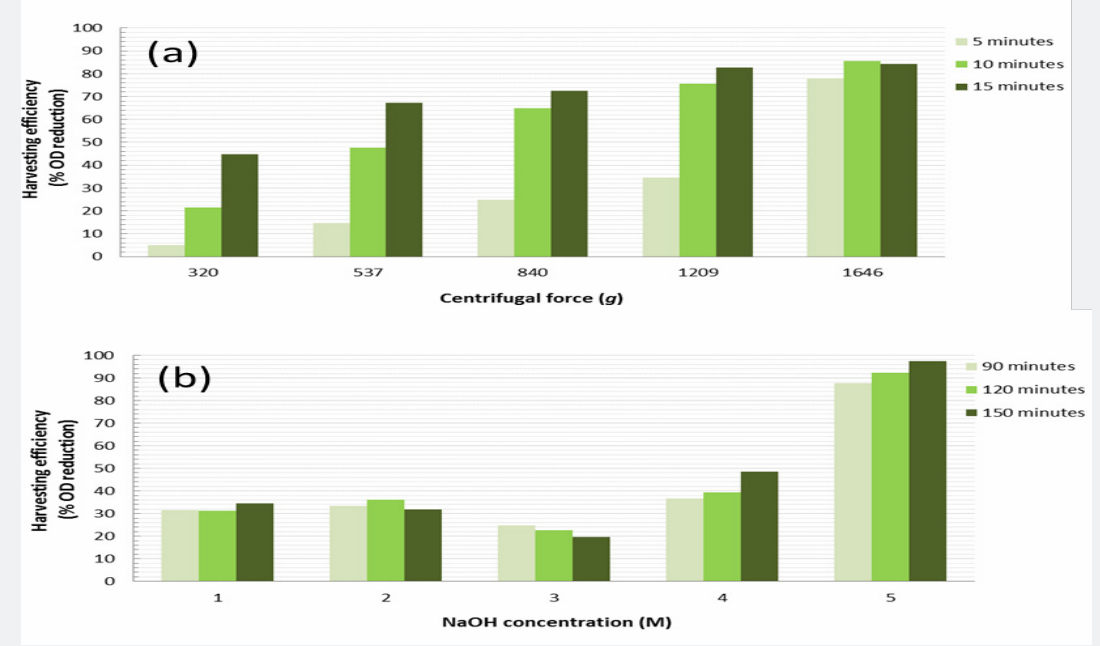

Figure 6: Harvesting efficiency in centrifugation process (a) and chemical flocculation (b) of S. maxima on exponential growth phase.

Considering influence of the biomolecules composition on buoyancy mechanism, it was examined the S. maxima harvest on different growth phases (Figure 6). In general, difference between cell content (i.e., dry mass from $0.4 \mathrm{~g} \mathrm{~L}^{-1}$ during exponential phase and $1 \mathrm{~g} \mathrm{~L}^{-1}$ during stationary phase) was not statistically significant during separation by centrifugation being maximum OD reduction from $86.1 \%$ at $1646 \mathrm{~g}$ during 15 minutes (harvested microalgae during stationary phase exhibited maximum OD reduction from $85.5 \%$ at $1646 \mathrm{~g}$ during 10 minutes - Figure 1). For chemical separation, statistically significant difference is observed at assays adding $5 \mathrm{M} \mathrm{NaOH}$. Harvested microalgae during exponential phase presented maximum recovery from $97.4 \%$ at $5 \mathrm{M} \mathrm{NaOH}$ during 150 minutes (assay realized during stationary phase shown maximum recovery from $80.7 \%$ for the same experimental conditions - Figure 2).

Among the prokaryotes, only cyanobacteria can carry out oxygenic photosynthesis with production of carbohydrates, proteins and lipids from carbon allocation [26]. Thus, cell growth implicates on cell density increase, gas-vacuolate reduction and lower buoyancy [25]. Light/Dark cycles during photosynthesis have direct effect on the photosynthesis/respiration balance. In addition, night respiratory losses can impact the yield of specific biomolecules [38]. Obtained results indicate exponential growth phase and dark cycle of the photoperiod more favorable to microalgae harvest by flotation.
Kim et al. [11] investigated influence growth phase on harvesting Spirulina platensis by flotation. Although gas vacuole synthesis exceeded the carbohydrate accumulation during stationary growth phase, the cells lose buoyancy impacting harvest by flotation. Harvested S. platensis on the exponential growth phase presented maximum recovery from $\sim 90 \%$ at $\mathrm{NaCl}$ 2\% during 150 minutes. Yi-Ru et al. [39] described that the Nannochloropsis maritima biomass increased gradually with the culture time reaching the maximum from $1.02 \mathrm{~g} \mathrm{~L}-1$. The $\mathrm{Fe}_{3} \mathrm{O}_{4}$ nanoparticles dosage required for achieving 95\% of recovery efficiency increased during the culture process.

\section{Conclusions}

Solid-liquid separation of the microalga Isochrysis galbana and cyanobacterium Spirulina maxima by different mechanisms with physical (i.e., centrifugation), chemical (i.e., chemical flocculant) and biological (i.e., temperature, irradiance, growth phase) action was explored. Obtained results in the present work suggest that the chemical flocculation of both strains presents best cost-benefit. During chemical flocculation, S. maxima harvested by flotation demonstrated lower water content than $I$. galbana harvested by gravity sedimentation. After initial harvest, water content within the I. galbana biomass can be reduced by centrifugation. Difference between cell content from different growth phases of $S$. maxima is significant for flotation efficiency. In this situation, harvested microalgae during exponential phase 
(containing lesser density) presented better recovery than assay realized during stationary phase. Thus, exponential growth phase and dark cycle of the photoperiod (night respiratory losses can impact the yield of specific biomolecules) are more favorable to $S$. maxima harvest by flotation.

\section{Acknowledgements}

R.R. S. and J. L. P gratefully acknowledge CNPq-Brazil [grant number 141295/2013-9] and PRH41/ANP- Brazil, respectively, for scholarship and financial support. J. L. M. and O. Q. F. A. gratefully acknowledge CNPq-Brazil [grant number 405851/2013-8] for research scholarship and financial support.

\section{References}

1. Federico V, Francisco J, Romero-Campero, Rosa L, Miguel GG, et al. (2016) New challenges in microalgae biotechnology. Eur J Protistol 55(Pt A): 95-101.

2. Hesam K, Shreeshivadasan C, Mohd FMD, Reza S, Shahabaldin R, et al. (2017) Evaluation of Lemna minor and Chlamydomonas to treat palm oil mill effluent and fertilizer production. J Water Process Eng 17: 229236.

3. Francesca R, Silvia B, Iago TDC, Iracema AN, Giovanni S, et al. (2017) Wastewater treatment by microalgae can generate high quality biodiesel feedstock. J Water Process Eng 18: 144-149.

4. Marta CP, José LM, Juliana GMM, Ricardo MC, Mario G, et al. (2013) A methodology for screening of microalgae as a decision-making tool for energy and green chemical process applications. Clean Technol Environ Policy 15(2): 275-291.

5. Monika H, Zoltan T, Katerina B (2015) Improving microalgae for biotechnology-From genetics to synthetic biology. Biotechnol Adv 33(6): 1194-1203.

6. Liam B, Philip O (2010) Biofuels from microalgae-a review of technologies for production, processing, and extractions of biofuels and co-products. Renew Sustainable Energy Rev 14(2): 557-577.

7. Emma S, Rosalam S (2012) Conversion of microalgae to biofuel. Renewable Sustainable Energy Rev 16(6): 4316-4342.

8. Selena D, Miranda M, Daniel F, Arsalon A, Serdar O, et al. (2016) A review of biodiesel production from microalgae. Clean Technol Environ Policy 19(3): 1-32.

9. Jungmin K, Gursong Y, Hansol L, Juntaek L, Kyochan K, et al. (2013) Methods of downstream processing for the production of biodiesel from microalgae. Biotechnol Adv 31(6): 862-876.

10. Dries V, Imogen F, Koenraad M (2013) Flocculation as a low-cost method for harvesting microalgae for bulk biomass production. Trends Biotechnol 31(4): 233-239.

11. Kim SG, Choi A, Ahn CY, Park CS, Park YH, et al. (2015) Harvesting of Spirulina platensis by cellular flotation and growth stage determination. Lett Appl Microbiol 40(3): 190-194.

12. Ami S, Doron E, Amicam B, Hilla C, Shai E, et al. (2012) Inexpensive non-toxic flocculation of microalgae contradicts theories; overcoming a major hurdle to bulk algal production. Biotechnol Adv 30(5): 10231030.

13. Ana IB, Ana LG, Manuel S, José CMP (2015) Harvesting techniques applied to microalgae: A review. Renew Sustainable Energy Rev 41: 1489-1500.

14. Robert RLG (1975) Culture of phytoplankton for feeding marine invertebrates In: Smith WL, Chanley MH. (Eds.) Culture of Marine Invertebrate Animals, Plenum, New York, USA, pp. 29-60.
15. Shuichi A, Takahira O (1977) Assessment of growth yield of a bluegreen alga, Spirulina platensis, in axenic and continuous culture. J Gen Microbiol I02: 179-182.

16. Zhu CJ, Lee KY (1997) Determination of biomass dry weight of marine microalgae. J Appl Phycol 9(2): 189-194.

17. Raquel RS, Ofélia QFA, José LM, Ricardo MC (2016) Cultivation of Spirulina maxima in medium supplemented with sugarcane vinasse. Bioresour Technol 204: 38-48.

18. David MH (1970) Process analysis by statistical methods, John Wiley \& Sons Inc., New York. 463 pp.

19. Zhu CJ, Lee YK, Chao TM (1997) Effects of temperature and growth phase on lipid and biochemical composition of Isochrysis galbana TK1. J Appl Phycol 9(5): 451-457.

20. Ahsan M, Habib B, Mashuda P, Tim CH, Mohammad RH (2008) A review on culture, production and use of Spirulina as food for humans and feeds for domestic animals and fish. FAO Fisheries and Aquaculture Circular, Rome.

21. Atiku H, Mohamed RMSR, Al-Gheethi AA, Wurochekke AA, Kassim AHM (2016) Harvesting of microalgae biomass from the phycoremediation process of greywater. Environ Sci Pollut Res 23(24): 1-18.

22. Stephen LP, Andrew KL, Theo K, Peter JA, Suraj S, et al. (2013) Harvesting, thickening and dewatering microalgae biomass. In: Borowitzka MA, Moheimani NR (eds.) Algae for biofuels and energy. Springer, Dordrecht, pp. 165-185.

23. Kim K, Shin H, Moon M, Ryu BG, Han JI, etal. (2015) Evaluation of various harvesting methods for high- density microalgae, Aurantiochytrium sp. KRS101. Bioresour Technol 198: 828-835.

24. Rita H, Simon AP, Bruce J (2008) The impact of algal properties and pre-oxidation on solid-liquid separation of algae. Water Res 42(8-9): 1827-1845.

25. Anthony EW (1994) Gas Vesicles. Microbiol Rev 58(1): 94-144.

26. John BW (2006) The Cyanobacteria - Isolation, purification and identification. Prokaryotes 4: 1053-1073.

27. Rafael S, Paulo CA (2015) Use of natural pH variation to increase the flocculation of the marine microalgae Nannochloropsis oculate. Appl Biochem Biotechnol 175(4): 2012-2019.

28. Luiz RIM, Ângelo PM, Gisele O, Ernani SS (2014) Floculação de Chlorella sp. produzida em concentrado de dessalinização e estudo de método de extração de lipídeos intracelulares. Quim Nova 37(1): 44-49.

29. Tawan C, Yusuf C (2016) Continuous flocculation-sedimentation for harvesting Nannochloropsis salina biomass. J Biotechnol 222: 94-103.

30. Zhao Y, Liang W, Liu L, Li F, Fan Q et al. (2015) Harvesting Chlorella vulgaris by magnetic flocculation using $\mathrm{Fe}_{3} \mathrm{O}_{4}$ coating with polyaluminium chloride and polyacrylamide. Bioresour Technol 198: 789-796.

31. Sanjaya L, Koenraad M, Tika BK, Imogen F, Rita KH, et al. (2016) Flocculation properties of several microalgae and a cyanobacterium species during ferric chloride, chitosan and alkaline flocculation. Bioresour Technol 220: 464-470.

32. Cláudia MLLT, Fabiana VK, Pedro CNT (2012) Evaluation of Moringa oleifera seed flour as a flocculating agent for potential biodiesel producer microalgae. J Appl Phycol 24(3): 557-563.

33. Ndikubwimana T, Zeng X, Murwanashyaka T, Manirafasha E, He N, et al. (2016) Harvesting of freshwater microalgae with microbial bioflocculant: a pilot-scale study. Biotechnol Biofuels 9: 47.

34. Xueqian L, Yao C, Zongze S, Zhangran C, Yi L, et al. (2015) Effective harvesting of the microalgae Chlorella vulgaris via flocculationflotation with bioflocculant. Bioresour Technol 198: 922-925. 
35. Yi Z, Mark R, Jesse K, Ning Z, Terry W (2015) Harvesting microalgae using the temperature-activated phase transition of thermoresponsive polymers. Algal Res 11: 90-94.

36. Beard SJ, Handley BA, Walsby AE (2002) Spontaneous mutations in gas vesicle genes of Planktothrix spp. affect gas vesicle production and critical pressure. FEMS Microbiol Lett 215(2): 189-195.

37. Li P, Song Y, Yu S, Park HD (2015) The effect of hydrodynamic cavitation on Microcystis aeruginosa: physical and chemical factors. Chemosphere 136: 245-251.

This work is licensed under Creative Commons Attribution 4.0 Licens

DOI: 10.19080/AIBM 2018.11.555819
38. Scott JE, Michael HH (2014) The dark side of algae cultivation: characterizing night biomass loss in three photosynthetic algae, Chlorella sorokiniana, Nannochloropsis salina and Picochlorum sp. Algal Res 12: 470-476.

39. Yi-Ru H, Feng W, Shi-Kai W, Chun-Zhao L, Chen G (2013) Efficient harvesting of marine microalgae Nannochloropsis maritima using magnetic nanoparticles. Bioresour Technol 138: 387-390.

\section{Your next submission with Juniper Publishers} will reach you the below assets

- Quality Editorial service

- Swift Peer Review

- Reprints availability

- E-prints Service

- Manuscript Podcast for convenient understanding

- Global attainment for your research

- Manuscript accessibility in different formats

( Pdf, E-pub, Full Text, Audio)

- Unceasing customer service

Track the below URL for one-step submission https://juniperpublishers.com/online-submission.php 